Article

\title{
Productive and economic response to concentrate supplementation by grazing dairy cows at high stocking
}

Benito Albarrán-Portillo ${ }^{a^{*}}$

Felipe López-González ${ }^{\mathrm{b}}$

Miguel Ruiz-Albarrán ${ }^{c}$

Carlos Manuel Arriaga-Jordán ${ }^{\mathrm{b}}$

a Universidad Autónoma del Estado de México. Centro Universitario UAEM Temascaltepec. Km 67.5 Carretera Toluca-Tejupilco, 51300.Temascaltepec, Estado de México. México.

${ }^{\mathrm{b}}$ Universidad Autónoma del Estado de México. Instituto de Ciencias Agropecuarias y Rurales. México.

${ }^{c}$ Universidad Autónoma de Tamaulipas. Facultad de Medicina Veterinaria y Zootecnia. México.

* Corresponding author: balbarranp@uaemex.mx

\begin{abstract}
:
Small-scale dairy systems contribute to ameliorate rural poverty and to local milk supply. Their sustainability is limited by high feeding costs, mainly from purchased concentrates (CC); whereas a higher reliance on quality forage may improve profitability; but high stocking rates may justify high $\mathrm{CC}$ use. The objective of this work was to assess the productive and economic response by grazing dairy cows to levels of $\mathrm{CC}$ under grazing of ryegrass-white clover pastures under high stocking rate (4 cows/ha). Six Holstein milking cows were replicated assigned 3 X 3 Latin Square arrangements. Daily milk yield and composition were recorded, and feed intake estimated from utilised metabolizable energy. Treatments were: $\mathrm{T} 1=1.0 \mathrm{~kg} \mathrm{~T} 6=3.0 \mathrm{~kg}$ and $\mathrm{T} 6=6.0 \mathrm{~kg}$ concentrate $/ \mathrm{cow} / \mathrm{d}$. There were significant differences $(P<0.05)$ for milk yield, with T6 having higher yields than T1 and T3. There were no significant differences in milk protein or fat content among treatments $(P>0.05)$. Herbage intake was significantly $(P<0.05)$ lower in T6, with no
\end{abstract}


differences $(P>0.05)$ between $\mathrm{T} 1$ and T3. There were no differences in margins over feeding costs, but feeding cost per kg of milk was 2.2 times higher in T6 compared to T1, and margin per kilo of milk was $26 \%$ higher in T1 than T6. Although milk yields are higher with T6, T1 and T3 require less expenditures and margins are similar. Supplementation may alleviate high grazing pressure that deteriorates pastures, ensuring the long-term sustainability of small-scale dairy farming systems.

Key words: Milk, Supplements, Concentrate, Intake, Stoking rate, Cost.

Received: 17/07/2018

Accepted: 18/09/2018

\section{Introduction}

Small-scale dairy systems in Mexico are a rural development option since they enable farming families to overcome poverty indices ${ }^{(1)}$. These systems are important in many areas of the world with common features to the highlands of Mexico ${ }^{(2)}$, like in other Latin American countries as in the Andean highland regions of Peru ${ }^{(3,4)}$ and $\mathrm{Uganda}^{(5)}$.

In Mexico, they are defined by small farms with herds between three and 35 cows plus replacements, and rely on their family labour ${ }^{(6)}$. Their sustainability is jeopardised by high feeding costs in the face of stagnated prices for milk, mainly due to their reliance on external inputs of which bought-in commercial compound concentrates represent the highest proportion of costs, since farmers believe that high levels of concentrate supplementation are essential for milk production, even at the moderate milk yields in these systems. Therefore, the economic scale limits their sustainability ${ }^{(6)}$.

A higher use of quality home-grown forages may increase the profitability and hence sustainability of these systems, as is the case for intensive grazing of temperate pastures in farms with access to irrigation, that has been shown to reduce feeding costs in these systems $^{(7)}$.

However, one limitation of grazing dairy cows is the low intake of dry matter ${ }^{(8)}$, particularly under high grazing pressure, so that concentrates may be required in these conditions to sustain milk yields. Small-scale dairy systems traditionally have more cattle than the carrying capacity of their small farms with stocking rates over 3.0 cows/ha of agricultural land ${ }^{(6)}$, so that a high concentrate use may be justified in these systems. 
Therefore, the objective of this work was to assess the productive and economic response of grazing dairy cows at a high stocking rate to increased levels of compound concentrate supplementation, as well as their effect on feed intake.

\section{Material and methods}

The work took place in Ejido San Cristóbal, a smallholder campesino village where most families are small-scale dairy farmers, located in the highlands of central Mexico at $19^{\circ}$ $24^{\prime} \mathrm{N}$ and $99^{\circ} 51^{\prime} \mathrm{W}$, at an altitude of $2,650 \mathrm{~m}$. The region has a sub-humid temperate climate with a distinct rainy season (May - October) and dry season (November - April), and average annual rainfall of $800-1,000 \mathrm{~mm}$ and a mean annual temperature of $13^{\circ} \mathrm{C}$. The experiment took place during the rainy season, from June $26^{\text {th }}$ to August $27^{\text {th }}$ of 2000 .

A demonstration module in feeding strategies for small dairy herds was established in consultation with the community on a $1.5 \mathrm{ha}^{-1}$ plot of the local school. A local participating farmer managed the module with a herd of six local milking cows following a participatory livestock technology research approach ${ }^{(9)}$ so that results were applicable by farmers in the region and other areas with similar systems.

\section{Experimental design}

Li Treatment sequences were randomised for Square 1, and Square 2 followed a mirror image in the treatment sequences to account for carry-over effects. Cows were assigned randomly to treatment sequence in both squares following previous work ${ }^{(10)}$.

Experimental periods lasted $21 \mathrm{~d}, 14$ for adaptation to diet and 7 as measurement period. Cows were hand milked twice daily at 0500 and $1800 \mathrm{~h}$.

Treatments were: $\mathrm{T} 1=1.0 ; \mathrm{T} 3=3.0$; and $\mathrm{T} 6=6.0 \mathrm{~kg}$ fresh basis $/ \mathrm{cow} / \mathrm{d}$ of commercial compound concentrate with $16 \% \mathrm{CP}$, respectively. Cows continuously grazed for 11 $\mathrm{h} / \mathrm{d}^{-1}$ with drinking water provided ad libitum at pasture (Lolium perenne and Trifolium repens). During nights, cows stayed indoors in a tie-stall and no feed was provided.

Milk yield was weighed daily during the 7 measurement days per experimental period with a spring balance using mean daily yield for analysis; and samples of milk taken in a morning and an afternoon milking to determine milk protein and milk fat content. 
Body condition score ( $1-5$ scale) was determined on the last day of each experimental period.

\section{Pasture establishment and grazing management}

The $1.5 \mathrm{ha}^{-1}$ were sown with a mixed pasture of perennial ryegrass (Lolium perenne cv. Nui), annual ryegrass (L. multiflorum cv. Tama) and white clover (Trifolium repens cv. Pitaw). The pasture was fertilized every $4 \mathrm{wk}$ with $75 \mathrm{~kg}$ of urea (46-0-0)/ha ${ }^{-1}$, and twice a year with $100 \mathrm{~kg} / \mathrm{ha}$ of triple super phosphate (0-46-0) and potassium chloride (0-0-60), respectively. Continuous (set-stocked) grazing took place from 0700 to $1800 \mathrm{~h}$ daily.

\section{Herbage measurements}

Estimation of net herbage accumulation (NHA) was from cutting to ground level with shears $0.5 \mathrm{~m}^{2}(2.0 \times 0.25 \mathrm{~m})$ quadrants, within five exclusion cages. NHA (Kg DM ha ${ }^{-1}$ $\mathrm{d}^{-1}$ ) was the difference between herbage cut inside the cage on $\mathrm{d} 21$ and herbage found outside the cage on $d 0$, then cages where placed randomly in the sward ${ }^{(11,12,13)}$. Samples of cut herbage were oven-dried $\left(60^{\circ} \mathrm{C}\right)$ air forced for DM analysis. These dry weights were used to calculate the herbage mass on a DM basis. Herbage height $(\mathrm{cm})$ was recorded with a rising plate metre twice weekly, taking 20 recordings following a zigzag pattern $^{(10,11)}$.

\section{Chemical composition of herbage and feeds}

Herbage was sampled by hand-plucking at the approximate height to which the cows grazed $^{(14,15)}$. During each measurement period herbage and concentrate were all analysed for dry matter (DM), organic matter by ashing (OM), crude protein $(\mathrm{CP})$, neutral detergent fibre (NDF), and acid detergent fibre (ADF) and estimated metabolizable energy (oME) content of herbage and concentrate were from in vitro digestibility by standard techniques following the procedures reported ${ }^{(1)}$. 


\section{Estimation of voluntary intake}

Herbage DM intake was estimated, indirectly, once during each measurement period from animal performance results ${ }^{(15,16)}$ as follows:

Herbage DM intake $\left(\mathrm{kg} \mathrm{DM} \mathrm{d}^{-1}\right)=\underline{\left(\mathrm{ME}_{\mathrm{m}}+\mathrm{ME}_{\mathrm{my}}+\mathrm{ME}_{\mathrm{lwc}}+\mathrm{ME}_{\mathrm{g}}\right)-(\text { supplement } \mathrm{ME})}$ herbage ME

where, $M E_{m}, M E_{m y}, M E_{1 w c}$ and $M E_{g}$ are the $M E$ requirements for maintenance, milk production, live weight change and gestation, respectively ${ }^{(17)}$, supplement ME supplied by the supplement, and herbage ME is the estimated ME concentration of herbage samples.

\section{Statistical analysis}

Animal variables were analysed as a replicated 3 x 3 Latin Square with the following $\operatorname{model}^{(10)}$ :

$\mathbf{Y}_{i j k l}=\mu+\mathrm{S}_{i}+\mathrm{C}_{j(i)}+\mathrm{P}_{k}+\mathrm{t}_{l}+e_{i j k l}$

Where:

$\mu=$ General mean;

$\mathbf{S}=$ effect due to squares. $i=1,2$;

$\mathbf{C}=$ effect due to cows within squares $j=1,2,3$;

$\mathbf{P}=$ effect due to experimental periods. $k=1,2,3$;

$\boldsymbol{t}=$ effect due to treatment. $l=1,2,3$;

$\boldsymbol{e}=$ residual error term .

Animal response variables were analyzed using MINITAB general linear model command (2003). Multiple comparisons between least squares means were performed using the Tukey test. Pastures variables (Table 1) were analyzed with one-way ANOVA using Microsoft Excel® data analysis package. 


\section{Economic analysis}

The economic analysis was performed using the partial budget approach ${ }^{(18)}$, to determine the economic profits due to the use of supplements, exclusively for milk. Economic analysis results are expressed in US dollars.

\section{Results}

Average temperature was $13.6^{\circ} \mathrm{C}$, with a maximum and minimum of 20.5 and $6.8{ }^{\circ} \mathrm{C}$, respectively. Total rain fall during the experiment was $332 \mathrm{~mm}$, distributed as follows 139, 122 and $61 \mathrm{~mm}$ in EP1, EP2 and EP3, respectively.

Table 1 shows results for net herbage accumulation (NHA) per period and per day, as well as mean sward height. Net herbage accumulation and DHA in EP3 were significantly higher than in EP one and two $(P<0.01)$.

Table 1: Net herbage accumulation (NHA) and sward height

\begin{tabular}{|c|c|c|c|c|c|}
\hline \multicolumn{6}{|c|}{ Period } \\
\hline Herbage mass & 1 & 2 & 3 & $P=$ & SD \\
\hline $\begin{array}{l}\text { NHA, } \\
\text { OM/ha/period }\end{array}$ & $1073.1^{\mathrm{a}}$ & $890.0^{\mathrm{a}}$ & $2024.5^{\mathrm{b}}$ & 0.01 & 609.0 \\
\hline $\begin{array}{l}\text { Daily NHA, } \mathrm{kg} \\
\text { OM/ha/d }\end{array}$ & $51.1^{\mathrm{a}}$ & $42.4^{\mathrm{a}}$ & $96.4^{\mathrm{b}}$ & 0.02 & 29.0 \\
\hline herbage height, $\mathrm{cm}$ & 3.0 & 2.4 & 5.5 & 0.21 & 1.6 \\
\hline
\end{tabular}

Table 2 shows the chemical composition of the pasture herbage. Crude protein and digestibility were not different across $\mathrm{EP}(P>0.05)$. Crude protein ranged from 122 to 162 (EP1 an EP3, respectively), with a mean of $147 \mathrm{~g} / \mathrm{kg}$ DM. Digestibility (Dig) mean digestibility was 581 (g/kg DM). Dry mater, ash, OM, NDF and ADF were significantly different across EP $(P<0.05)$. Estimated metabolizable energy $(\mathrm{eME})$ was different $(P<0.001)$ among EP, the lowest value was in EP1 (10.1), whereas EP2 and 3, were not different among each other (11.2 and 11.2 MJ ME/kg DM). 
Table 2: Chemical composition of herbage

\begin{tabular}{|c|c|c|c|c|c|}
\hline & \multicolumn{3}{|c|}{ Period } & \multirow[t]{2}{*}{$\boldsymbol{P}$} & \multirow[t]{2}{*}{ SD } \\
\hline & $\mathbf{1}$ & 2 & 3 & & \\
\hline Dry matter, $\mathrm{g} \mathrm{kg}^{-1}$ & $275.5^{\mathrm{a}}$ & $346.9^{\mathrm{b}}$ & $262.1^{\mathrm{a}}$ & 0.001 & 45.6 \\
\hline Ash, $\mathrm{g} \mathrm{kg}_{-}{ }^{1}$ & $265.2^{\mathrm{a}}$ & $230.2^{\mathrm{a}}$ & $97.6^{\mathrm{b}}$ & 0.03 & 0.1 \\
\hline Organic matter, $\mathrm{g} \mathrm{kg}^{-1}$ & $734.8^{\mathrm{a}}$ & $769.8^{a}$ & $902.4^{\mathrm{b}}$ & 0.001 & 32.3 \\
\hline Crude protein, $\mathrm{g} \mathrm{kg}^{-1} \mathrm{DM}$ & 160.4 & 121.5 & 161.9 & 0.08 & 75.3 \\
\hline Neutral detergent fibre, $\mathrm{g} \mathrm{kg}^{-1} \mathrm{DM}$ & $572.4^{\mathrm{a}}$ & $473.8^{\mathrm{b}}$ & $517.9^{a}$ & 0.001 & 49.4 \\
\hline Acid detergent fibre, $\mathrm{g} \mathrm{kg}^{-1} \mathrm{DM}$ & $474.3^{\mathrm{a}}$ & $247.9^{b}$ & $260.5^{b}$ & 0.01 & 127.2 \\
\hline Digestibility of organic matter, $\mathrm{g} \mathrm{kg}^{-1} \mathrm{DM}$ & 602.3 & 559.7 & NA & 0.11 & 347.1 \\
\hline Metabolizable energy, $\mathrm{MJ} \mathrm{kg}^{-1} \mathrm{DM}$ & $10.1^{\mathrm{a}}$ & $11.2^{\mathrm{b}}$ & $11.1^{\mathrm{b}}$ & 0.001 & 0.91 \\
\hline
\end{tabular}

Table 3 shows the results for feed intake, with significant differences $(P<0.05)$ among treatments. There were no differences between $\mathrm{T} 1$ and $\mathrm{T} 2$ in herbage intake but lower intake in T6. Due to concentrate supplementation, total feed intake was not significantly different $(P>0.05)$ between T3 and T6, but total intake was significantly lower $(P<0.05)$ for T1. In time, there was a reduction in herbage intake, in Period 2, in spite of improved grazing conditions; this, lead to a significantly lower total intake $(P<0.05)$ in Period 2 , compare to periods one and three.

Table 3: Feed intake by treatments and periods $\mathrm{kg}(\mathrm{OM} / \mathrm{cow} / \mathrm{d})$

\begin{tabular}{|c|c|c|c|c|c|}
\hline \multicolumn{6}{|c|}{ Treatments } \\
\hline Intake & T1 & T3 & T6 & $P$ & SEM \\
\hline Concentrate & 0.9 & 2.6 & 5.3 & & \\
\hline Herbage & $8.2^{\mathrm{a}}$ & $7.3^{\mathrm{a}}$ & $6.1^{\mathrm{b}}$ & 0.001 & 0.5 \\
\hline Total & 9.1 & 9.9 & 11.4 & 0.17 & 0.7 \\
\hline \multicolumn{6}{|c|}{ Period } \\
\hline Intake & 1 & 2 & 3 & & \\
\hline Concentrate & 2.9 & 2.9 & 2.9 & & \\
\hline Herbage & $7.3^{\mathrm{a}}$ & $6.9^{\mathrm{b}}$ & $7.3^{\mathrm{a}}$ & 0.04 & 0.5 \\
\hline Total & $10.2^{\mathrm{a}}$ & $9.8^{\mathrm{b}}$ & $10.2^{\mathrm{a}}$ & 0.001 & 0.7 \\
\hline
\end{tabular}


There were significant differences $(P<0.05)$ among treatments for milk yields (Table 4$)$; with no differences between $\mathrm{T} 1$ and $\mathrm{T} 3$, which were significantly different $(P<0.05)$ from T6 which had the highest yield.

Table 4: Milk yield and milk composition by treatment and periods

\begin{tabular}{lllll}
\hline Treatment & T1 & T3 & T6 & $P$ \\
\hline Milk yield, kg/cow/d & $11.3^{\mathrm{a}}$ & $12.6^{\mathrm{a}}$ & $15.8^{\mathrm{b}}$ & 0.02 \\
Milk fat content, g/kg & 37.8 & 37.6 & 33.8 & 0.59 \\
Milk protein content, g/kg & 35.1 & 32.8 & 33.0 & 0.91 \\
\hline \multicolumn{1}{c}{$\quad$ Period } & 1 & 2 & 3 & $P$ \\
\hline Milk yield, kg/cow/d & - & 11.3 & 14.1 & 0.11 \\
Milk fat content, g/kg & 38.5 & 35.6 & 35.5 & 0.60 \\
Milk protein content, g/kg & 30.6 & 36.3 & 34.0 & 0.11 \\
Body condition score & 1.8 & 1.8 & 1.8 &
\end{tabular}

Table 5 shows results for feeding costs (in US dollars). Increased concentrate supplementation increased feeding costs. Total feeding costs in T6 are almost three times the feeding cost in T1, whilst milk income was only $28 \%$ higher, which results in a feeding cost per kilo of milk 2.2 times more expensive in T6 than in T1; with figures for T3 intermediate. Profit per kilogram of milk was therefore $33 \%$ higher in T1 than in T6. 
Table 5: Feeding costs for milk production at three levels of concentrate supplementation (US\$)

\section{Treatments}

$\begin{array}{lll}\text { T1 } & \text { T3 } & \text { T6 }\end{array}$

Cost of feed inputs:

\begin{tabular}{llll} 
Concentrate & 24.5 & 76.4 & 152.8 \\
Pasture & 37.5 & 36.4 & 26.3 \\
Total feeding costs & 63.0 & 112.8 & 179.1 \\
$\quad$ Returns: & & & \\
Milk production, kg & $1,311.3$ & $1,459.6$ & $1,691.8$ \\
Total returns for milk sales & 388.5 & 432.5 & 501.3 \\
Margin over feed costs & 325.5 & 319.6 & 322.1 \\
Returns / feeding costs ratio & 6.2 & 3.8 & 2.8 \\
Feeding cost, (US\$/kg milk) & 0.05 & 0.08 & 0.11 \\
Sale price of milk, (US\$/kg) & 0.29 & 0.29 & 0.29 \\
Margin per kilo $(\mathrm{US} \$ / \mathrm{kg})$ & 0.24 & 0.21 & 0.18 \\
\hline
\end{tabular}

$\mathrm{T} 1=1 ; \mathrm{T} 3=3 \mathrm{y} \mathrm{T} 6=6 \mathrm{~kg}$ of concentrate $\mathrm{DM} \mathrm{cow}{ }^{-1} / \mathrm{d}$.

\section{Discussion}

The effect of weather condition is reflected in the chemical composition of the herbage throughout the different growing seasons. This grazing season was characterized by low herbage growth rate, short regrowth, low herbage mass availability and low herbage intake. In addition, grass development was based on vegetative growth, characterized with higher proportions of grass leaf, lower proportions of grass stem and dead material, and more digestible than other vegetative state. Temperate herbages used for dairy cows are described as high quality when chemical composition is around 180-240 g DM kg- ${ }^{1}$, 180 to $250 \mathrm{~g} \mathrm{CP} \mathrm{kg-}^{1}{ }^{1} \mathrm{DM}$, 400 to $500 \mathrm{~g} \mathrm{NDF} \mathrm{kg-}^{1} \mathrm{DM}$, and 10.47 to $12.14 \mathrm{MJ} \mathrm{ME} \mathrm{kg-}^{1}$ $\mathrm{DM}^{(19)}$. Under the conditions of this experiment, herbage was characterized by low concentrations of crude protein, low energy and low amounts of non-structural carbohydrates and DM. 
Crude protein content of pasture herbage was lower than a report in southern Brazil ${ }^{(20)}$, and lower than reports of work undertaken in the same study area ${ }^{(21,22)}$; but sufficient to meet protein requirements for moderate yielding dairy cows ${ }^{(23)}$.

Structural carbohydrate content determines digestibility, intake, and the nutritional value of forages. Average values of NDF and ADF of pasture herbage were 521.37 and 327.57 $\mathrm{g} / \mathrm{kg} \mathrm{DM}$, respectively; lower from reports in a previous work in the same area, but during the dry season ${ }^{(24)}$.

Estimated metabolizable energy was $10.8 \mathrm{MJ} / \mathrm{kg}$ DM on average (Table 2) representing an herbage of good quality. However, this value is lower than reports of $12.3 \mathrm{MJ} \mathrm{EM} / \mathrm{kg}$ DM in the highlands of Mexico ${ }^{(10)}$, or 11.2 MJ EM/kg DM reported in New Zealand ${ }^{(25)}$. The interaction of lower energy content and herbage availability may explain low intakes and low milk yields observed (Tables 3 and 4).

Net herbage accumulation was low during periods 1 and 2, which given the high stocking rate, resulted in a high grazing pressure and low herbage availability, with very low sward metre heights. Improved grazing conditions in terms of herbage growth and availability for Period 3, enabled cows to recover milk yields similar to those of Period 1, overcoming the loss of almost $3 \mathrm{~kg} / \mathrm{cow} / \mathrm{d}^{-1}$ from Period 1 to Period 2 as grazing conditions deteriorated.

Difficult grazing conditions with low herbage availability and moderate milk yields resulted in low herbage intakes, which were significantly decreased $(P<0.05)$ by the high supplementation rate in T6, with high substitution rates.

It has been reported that $0.31 \mathrm{~kg} / \mathrm{d}^{-1}$ of concentrate supplemented to grazing dairy cows results in a $1.0 \mathrm{~kg}$ DM reduction in herbage intake ${ }^{(26)}$. Nonetheless, herbage intake in the experiment herein reported was similar to reports by ${ }^{(27,28)}$ with grazing dairy cows in low herbage mass pastures during winter in France, reporting a mean daily intake of $7.2 \mathrm{~kg}$ $\mathrm{DM} / \mathrm{cow}$.

Observed milk yields were lower that results for grazing cows reported by in the USA ${ }^{(26)}$, in the $\mathrm{UK}^{(29)}$, in southeast $\mathrm{USA}^{(30)}$, and in Mexico ${ }^{(24)}$. However, observed milk yields were similar to reports by others ${ }^{(27)}$ from cows under difficult grazing conditions in western France, illustrating the fact that difficult grazing conditions limit intake, and yields, particularly during late lactation.

Milk fat contents of milk are similar to results reported in France ${ }^{(27)}$, in Spain ${ }^{(31)}$, and in Chile $^{(32)}$. Although there were no statistical differences in milk fat content $(P>0.05)$ there was a trend towards lower content in the high supplementation treatment T6.

Protein content of milk was higher than reports from works in Mexico with small-scale dairy farmers ${ }^{(33,34)}$, as well as higher than reports from $\mathrm{Chile}^{(32)}$; but similar to milk protein content from a study in the $\mathrm{UK}^{(29)}$.

In terms of feeding costs and returns, in spite of lower yields for $\mathrm{T} 1$ and $\mathrm{T} 3$ compared to T6, the margin over feeding costs is similar for the three treatments. However, in terms 
of feeding cost per $\mathrm{kg}$ of milk and profit over feeding costs, $\mathrm{T} 1$ has lower cost and higher profit. Feeding cost per kilo of milk was 2.5 times higher in T6 compared to T1, and margin was $25 \%$ higher in $\mathrm{T} 1$ than $\mathrm{T} 6$, with $\mathrm{T} 3$ showing intermediate economic results. Low feeding costs and similar margins among treatments result in a very high returns / feeding costs ratio for $\mathrm{T} 1$ compared to $\mathrm{T} 6$.

\section{Conclusions and implications}

In conclusion, there is no economic benefit of increased concentrate supplementation since total margins over feeding costs are similar; and farmers need a greater cash flow to cover the increased costs of higher amounts of concentrate used. However, there is a need for long-term experiments since supplementation alleviates the grazing pressure due to high stocking rates. NHA was low resulting in difficult grazing conditions limiting the intake of cows. Forage or by-products of lower cost than commercial compound feeds may also be an alternative to sustain cow and pasture productivity. An optimal compromise in productive, economic and in the soundness of the pasture will ensure the long term sustainability of these small-scale farming systems.

\section{Acknowledgements}

To all the members of Ejido San Cristóbal, particularly to Mr. Hermenegildo ReyesReyes, the participating farmer in charge of the demonstration module, for his enthusiastic and full support to the project. Ms. Laura Edith Martínez-Contreras and Ms. Irma LópezAnaya (RIP) for chemical analysis. Thanks are given to Consejo Nacional de Ciencia y Tecnología - CONACYT for funding this work (grant 28888-B). 


\section{Literature cited:}

1. Espinoza-Ortega A, Espinosa-Ayala E, Bastida-López J, Castañeda-Martínez T, Arriaga-Jordán CM. Small-scale dairy farming in the highlands of central Mexico: Technical, economic and social aspects and their impact on poverty. Exp Agr 2007;43:241-256.

2. Cortez-Arriola J, Groot CJJ, Walter AH, Rossing AHW, Scholberg MSJ, AméndolaMassiotti RD, Tittonell P. Alternative options for sustainable intensification of smallholder dairy farms in North-West Michoacán, Mexico. Agric Syst 2016;144:22-32.

3. Bartl K, Mayer AC, Gómez CA, Muñoz E, Hess HD, Holmann F. Economic evaluation of current and alternative dual-purpose cattle systems for smallholder farms in the central Peruvian highlands. Agr Syst 2009;101:152-161.

4. Okello S, Sabiiti EN, Schwartz HJ. Analysis of factors affecting milk yield of Ankole cows grazed on natural range pastures in Uganda. Afr J Range Sci 2005;22:149-156.

5. Kiggundu M, Kabi F, Mette V, Nalubwama S, Odhong C. Management and use of dairy cattle feed resources on smallholder certified organic pineapple farms in Central Uganda. J Agr Environ Int Dev 2014;108:207-225.

6. Fadul-Pacheco L, Wattiaux MA, Espinoza-Ortega A, Sánchez-Vera E, ArriagaJordán CM. Evaluation of sustainability of smallholder dairy production systems in the highlands of Mexico during the rainy season. Agroecol Sust Food 2013;37:882901.

7. Pincay-Figueroa PE, López-González F, Velarde-Guillén J, Heredia-Nava D, Martínez-Castañeda FE, Vicente F, et al. Cut and carry vs. grazing of cultivated pastures in small-scale dairy systems in the central highlands of Mexico. J Agr Environ Int Dev 2016;110:349-363.

8. Kolver ES, Muller LD. Performance and nutrient intake of high producing Holstein cows consuming pasture or a total mixed ration. J Dairy Sci 1998;81:1403-1411.

9. Conroy C. Participatory Livestock Research. Bourton-on-Dunsmore, Warwickshire, UK, ITDG Publishing; 2005.

10. Celis-Alvarez MD, López-González F, Martínez-García CG, Estrada-Flores JG, Arriaga-Jordán CM. Oat and ryegrass silage for small-scale dairy systems in the highlands of central Mexico. Trop Anim Health Prod 2016;48:1129-1134.

11. Sainz-Sánchez PA, López-González F, Estrada-Flores JG, Martínez-García CG, Arriaga-Jordán CM. Effect of stocking rate and supplementation on performance of dairy cows grazing native grassland in small-scale systems in the highlands of central Mexico. Trop Anim Health Prod 2017;49:179-186. 
12. Shakhane LM, Mulcahy C, Scott JM, Hinch GN, Donald GE, Mackay DF. Pasture herbage mass, quality and growth in response to three whole-farmlet management systems. Anim Prod Sci 2013;53:685-698.

13. McCarthy B, Pierce KM, Delaby L, Brennan A, Fleming C, Horan B. The effect of stocking rate and calving date on grass production, utilization and nutritive value of the sward during the grazing season. Grass Forage Sci 2013;68:364-377.

14. Soca P, Gonzalez H, Manterola H, Bruni M, Mattiauda D, Chilibroste P, Gregorini P. Effect of restricting time at pasture and concentrate supplementation on herbage intake, grazing behaviour and performance of lactating dairy cows. Livest Sci 2014;170:35-42.

15. Sheahan AJ, Gibbs SJ, Roche JR. Timing of supplementation alters grazing behavior and milk production response in dairy cows. J Dairy Sci 2013;96:477-483.

16. Rojas-Garduño M, Balocchi O, Vicente F, Pulido R. Effect of supplementation with cracked wheat or high moisture corn on milk fatty acid composition of grazing dairy cows. Chilean J Agric Res 2018;78:96-105.

17. AFRC - Agricultural and Food Research Council. Energy and protein requirements of ruminants. Wallingford, UK, CAB International;1993.

18. Espinoza-Ortega A, Espinosa-Ayala E, Bastida-López J, Castañeda-Martínez T, Arriaga-Jordán CM. Small-Scale dairy farming in the highlands of central Mexico: technical, economic and social aspects and their impact on poverty. Exp Agr 2007;43:241-256.

19. Ruiz-Albarran M, Balocchi O, Wittwer F, Pulido R. Milk production, grazing behavior and nutritional status of dairy cows grazing two herbage allowances during winter. Chilean J Agric Res 2016;76:34-39.

20. Miguel MF, Ribeiro-Filho H, Mendonça NA, De Andrade EG, Moraes TC, Delagarde R. Pasture intake and milk production of dairy cows grazing annual ryegrass with or without corn silage supplementation. Anim Prod Sci 2014;54:18101816.

21. Heredia-Nava D, Espinoza-Ortega A, González-Esquivel CE, Arriaga-Jordán CM. Feeding strategies for small-scale dairy systems based on perennial (Lolium perenne) or annual (Lolium multiflorum) ryegrass in the central highlands of México. Trop Anim Health Prod 2007;39:179-188.

22. Hernández-Ortega M, Heredia-Nava D, Espinoza-Ortega A, Sánchez-Vera E, Arriaga-Jordán CM. Effect of silage from ryegrass intercropped with winter or common vetch for grazing dairy cows in small-scale dairy systems in Mexico. Trop Anim Health Prod 2011;43:947-954. 
23. ARC - Agricultural Research Council. The nutrient requirements of ruminant livestock. Slough, UK, Published on behalf of the Agricultural Research Council by Commonwealth Agricultural Bureaux. 1980.

24. Albarrán B, García A, Espinoza A, Espinosa E, Arriaga CM. Maize silage in the dry season for grazing dairy cows in small-scale production systems in Mexico's Highlands. Indian J Anim Res 2012;46:317-324.

25. Bryant RH, Dalley DE, Edwards GR. Effect of grazing management on herbage protein concentration, milk production and nitrogen excretion of dairy cows in midlactation. Grass Forage Sci 2013;69:644-654.

26. Bargo F, Muller LD, Delahoy JE, Cassidy TW. Milk response to concentrate supplementation of high producing dairy cows grazing at two pasture allowances. $\mathrm{J}$ Dairy Sci 2002;85:1777-1792.

27. Pérez-Prieto LA, Peyraud JL, Delagarde R. Pasture intake, milk production and grazing behaviour of dairy cows grazing low-mass pastures at three daily allowances in Winter. Livest Sci 2011;13:151-160.

28. Pérez-Prieto LA, Peyraud JL, Delagarde R. Substitution rate and milk yield response to corn silage supplementation of late-lactation dairy cows grazing low-mass pastures at 2 daily allowances in autumn. J Dairy Sci 2011;94:3592-3604.

29. Hernández-Mendo O, Leaver JD. Production and behavioral responses of high- and low-yielding dairy cows to different periods of access to grazing or to a maize silage and soybean meal diet fed indoors. Grass Forage Sci 2006;61:335-346.

30. Macoon B, Sollenberger LE, Staples CR, Portier KM, Fike JH, Morell JE. Grazing management and supplementation effects on forage and dairy cow performance on cool-season pastures in the southeastern United States. J Dairy Sci 2011;94:39493959.

31. Vázquez-Yañez OP, González-Rodríguez A, López-Díaz JE. Efecto de la suplementación con concentrado sobre el aprovechamiento de la hierba y el rendimiento de vacas lecheras durante el pastoreo de primavera en la costa norte de Galicia. Pastos 2010;40:83-104.

32. Ruiz-Albarrán M, Balocchi OA, Noro M, Wittwer F, Pulido RG. Effect of increasing pasture allowance and grass silage on animal performance, grazing behaviour and rumen fermentation parameters of dairy cows in early lactation during autumn. Livest Sci 2012;150:407-413.

33. Bernal-Martínez LR, Rojas-Garduño MA, Vázquez-Fontes C, Espinoza-Ortega A, Estrada-Flores J, Castelán-Ortega OA. Determinación de la calidad fisicoquímica de la leche cruda producida en sistemas campesinos en dos regiones del Estado de México. Vet Mex 2007;38:395-407. 
34. Martínez-García CG, Rayas-Amor AA, Anaya-Ortega JP, Martínez-Castañeda FE, Espinoza-Ortega A, Prospero-Bernal F, Arriaga-Jordán CM. Performance of smallscale dairy farms in the highlands of central Mexico during the dry season under traditional feeding strategies. Trop Anim Health Prod 2015;47:331-337. 